\title{
Corporate governance and proactive environmental management in Novo Hamburgo and neighbouring cities, Brazil
}

\author{
Naime, R. ${ }^{a *}$, Spilki, FR. ${ }^{a}$ and Nascimento, CA. ${ }^{a}$ \\ aUniversidade Feevale, RS 239, 2755, CEP 93.352-000, Novo Hamburgo, RS, Brazil \\ *e-mail: rnaime@feevale.br
}

Received: May 24, 2013 - Accepted: August 12, 2013 - Distributed: May 31, 2015

(With 8 figures)

\begin{abstract}
This study compiled data on environmental auditing and voluntary certification of environment-friendly businesses of the Commercial and Industrial Association of Novo Hamburgo, Campo Bom and Estância Velha and analysed them according to classical environmental management principles: sustainable development and corporate governance. It assessed the level of application of the concepts of corporate governance to everyday business in companies and organisations and estimated how the interconnection and vertical permeability of these concepts might help to make bureaucratic environmental management systemic, proactive and evaluative, changes that may add great value to the operations evaluated. Results showed that, when analysing only audited items not directly defined in legislation, no significant changes were identified. The inclusion of more advanced indices may promote the transition from bureaucratic management, which meets regulated environmental standards only satisfactorily, into proactive and systemic environmental management, which adds value to companies and helps to perpetuate them. Audited and analysed data did not reveal actions that depend on the internal redistribution of power and the interconnection or verticality of attitudes that may materialize concepts of corporate governance.
\end{abstract}

Keywords: management, environment, corporate governance.

\section{Governança corporativa e manejo ambiental pró-ativo em Novo Hamburgo e cidades vizinhas, Brasil}

\begin{abstract}
Resumo
O presente estudo é uma compilação dos dados resultantes das ações de auditoria ambiental da certificação ambiental voluntária empresa amiga do meio ambiente da Associação Comercial e Industrial de Novo Hamburgo, Campo Bom e Estância Velha, os quais são analisados, considerando as premissas mais clássicas da gestão ambiental, quais sejam, o desenvolvimento sustentável e governança corporativa. O objetivo é avaliar o nível de aplicação das concepções de governança corporativa no cotidiano das empresas, empreendimentos ou organizações e verificar o quanto a permeabilidade e imbricação vertical destes conceitos poderia auxiliar na transformação da gestão ambiental burocrática numa ação de gestão ambiental sistêmica, proativa e valorativa, trazendo maior valor agregado para as operações avaliadas. Os resultados demonstram que quando são analisados itens auditados que não estejam diretamente relacionados com legislação e sanções aplicáveis, não ficam claros os possíveis indicativos de melhorias de gestão e processos. A inclusão de indicadores mais avançados significaria a passagem de uma gestão ambiental burocrática, que atende apenas satisfatoriamente normas regulamentadas a uma gestão ambiental sistêmica e proativa, que possa trazer maior valor agregado e perenização aos empreendimentos. Todas as ações que depende mais de redistribuição interna de poder e imbricação vertical ou permeabilidade de atitudes que materializem concepções de governança corporativa não são identificadas pelos dados auditados e analisados.
\end{abstract}

Palavras-chave: gestão, ambiente, governança corporativa.

\section{Introduction}

There is a growing concern about environmental issues worldwide, as well as about the growth of barriers to the international trade of several products, particularly those produced by companies in traditional industries in developing countries and which affect the environment considerably. The use of environmental management tools has been a consensus in the mitigation of impacts and the production of environmentally-friendly products. To make the use of these tools more efficient, companies have adopted corporate governance principles that are not only put into 
practice in the higher ranks of organisations, but are also disseminated and closely followed in organisations. Therefore, the expertise of technicians and other employees is used to achieve the best performance in production, workplace safety, occupational health and environmental management. An important element in businesses between countries, environmental protection has drawn increased attention from buyers. Adding environmental management to their internal policies, companies simultaneously conform to enacted legislation and contribute to society by investing more in clean technologies and products that cause a lower environmental impact (Naime and Garcia, 2004).

Some of the driving forces of globalisation have been the search for new markets and the efforts to reduce costs. However, that does not mean that business should only be done abroad; it also means an increase in competition for all types of organisations. Numerous organisations have also seen international growth as an incentive to have greater cost advantages over their competition. National borders have become increasingly less significant in the definition of business frontiers. According to Robbins (2003, p. 6), "advances in communications technologies and the reduction of trade barriers have contributed to the creation of a true global village".

Globalisation has brought about several changes, such as the opening of the limits of organisational operations. There have been technological changes in the access to information and the way it is generated, stored, used and shared, new employment opportunities open to knowledge worker, renewed respect to the cultural diversity of different populations, new social responsibilities accepted by companies and the need to understand that client perceptions and values shape business environments (Robbins, 2003, p. 7). Globalisation also led to greater concerns with the planet's environmental issues as a whole. According to Drucker (apud Maimon, 1996), ecology globalisation, which occurs in the context of the globalisation of economic relations, has intensified since the 1980s, when pollution phenomena transcended national borders and affected other regions and the entire planet. That gave rise to concerns about global risks, such as the contamination of soil, water, air and food chains, the green house effect, acid rain, demographic explosion and loss of biodiversity, particularly due to forest devastation.

According to Naime (2004, p. 13), “environmental management is the set of procedures and norms for the management of legal, ethical and practical questions of how to relate to the physical, biological and anthropic elements that make up the environment." The aim of environmental management is to identify the most adequate actions to conform to legal determinations and achieve actual and practical solutions for the entire process. Ecological management implies the passage from a mechanistic to a systemic approach. An essential aspect of such change is the fact that the perception of the world as a machine should be replaced with the perception of the world as a living system. This change affects our concept of nature, human organism, society and, therefore, also our perception of a business organisation. Companies are living systems that cannot be understood from a merely economic standpoint (Andrade et al., 2002).

According to the Instituto de Pesquisas Tecnológicas (Bos, 2006, p. 26), "environmental impacts depend on the nature of processes, raw materials, efficiency of each operation, management standards, residues and their treatability, the context in which corporate units operate and their density." Therefore, the concentration of companies in industrial areas, such as Novo Hamburgo, results in more intense impact generation, but may, at the same time, provide the synergy and the scale that are necessary to visualise solutions.

The Commercial and Industrial Association of Novo Hamburgo, Campo Bom and Estância Velha (ACI NH-CB-EV), represented by its environmental chapter, the Fundação Desenvolvimento Ambiental (FUNDAMENTAL), created and established a voluntary and informal environmental certification called Environmentally-Friendly Company in 2003 and 2004. Its major purpose was to motivate companies to disseminate their good environmental management initiatives to the entire community. The auditing costs of this certification are supported by ACI and, therefore, there are no costs for those certified.

Some basic items are evaluated in the area of ecodesign, optimisation of the use of water resources, power efficiency, effluent treatment, solid residues management, air monitoring, institutional environmental management actions, environmental education initiatives and socio-environmental responsibility programs in general.

After the statistical analysis of these variables, data are interpreted according to the stage of corporate governance achieved by the participants and the substantiated connections that may lead to proactive environmental management actions that go beyond conforming to legislation and promote commitment to stakeholders.

This study is a statistical compilation used for hypothetical and deductive considerations about the meaning of the data collected in the implementation of corporate governance and its imbrications in the different areas of organisations, as well as the results of proactive environmental management actions that meet relevant social expectations of the communities of the cities of the Sinos River basin, in the metropolitan area of Proto Alegre, the capital city of the state of Rio Grande do Sul, Brazil.

The data used were retrieved from the 2009 issue of the Environmentally-Friendly Company of ACI NH-CB-EV voluntary environmental certification programme.

The greatest motivation to invest in environmental management and ecologically correct products is the vision that companies will only be competitive in the market if they have a responsible environmental attitude.

The notion of sustainability was born in the concept of living with dignity and protecting the necessary resources for the survival of future generations. Naime (2004) translated this concept for companies and organisations as a collection of factors called "life in balance", which includes ecodesign, optimisation of water resources use, power 
efficiency, effluent, water and sewage treatment, solid residue management, air monitoring and socio-environmentally responsible actions.

Consumers are increasingly more aware of environmental issues, and competition between both companies and brands is generated as they seek to respond to customer needs. According to Maimon (1996), Kinlaw (1997), Moura (2003, 2004), Zenone (2006), Polonsky and Voltolini (apud Vilela Júnior and Demajorovic, 2006), there seems to be an interest in sustainable development and the simultaneous search for economic efficiency, social justice and ecological harmony. A growing number of organisations are joining "green marketing" and gaining the benefits of the many competitive opportunities offered by environmental issues.

In the search for ecologically-correct products or products with a lower environmental impact, several relevant issues have been raised by professional in the tannery and leather industry: the use of restrictive substances, non-tariff barriers, the search for important brands that may sell their products to improve their corporate image and future market trends.

According to Püntener (2007), the global concern with safety in using and handling chemicals and products containing chemicals led the European Union to create the Regulation on Registration, Evaluation and Authorisation and Restriction of Chemicals (REACH) in 2007, a new effort to coordinate global policies for chemicals and their residues.

Another relevant perception in the search for ecologically-correct products and products with a lower environmental impact was the establishment of non-tariff barriers. According to Maimon (1996), Moura (2004), Bos (2006), Henrique (2005) and Fornasari, Coelho and Santos (apud Bos, 2006), after the fall of tariff barriers, international trade has developed new forms of protectionism, expressed in the choice of companies and products from consolidated or newly created commercial blocs and in the increase of the number of non-tariff barriers or technical certification requirements. Great brands, markets and companies concerned with environmental issues are sought. Companies do not always have to undergo audits by certification organisations, but should prove to have an autonomous environmental management system, meet local legislation, act proactively in the area and have responsible attitudes. Therefore, they should be ready to be audited by their own clients, suppliers and non-governmental organisations concerned with these issues. These definitions are in agreement with those made by Maimon (1996), Layrargues (2000), Kinlaw (1997), Moura (2004).

Certifications such as the NBR ISO 14001:2004 environmental norms have also been demanded by clients both in the internal and in the external markets.

Third-party external auditing (auditing bodies) is expensive and, therefore, only adopted when the company feels that certifications are necessary to communicate with the external public and to add socio-environmental responsibility to its external image. In this context, certifications are a guarantee of market competitiveness, a current trend, in agreement with Moura (2004), Zenone (2006), Ruiz et. al. (2006), Fornasari and Coelho (apud Bos, 2006), Kinlaw (1997), Layrargues (2000), Andrade et al. (2002) and Epelbraum (apud Vilela Júnior and Demajorovic, 2006). Large and midsize companies can afford the high costs of investments in ecologically-satisfactory products and processes, but small companies tend to lose competitiveness due to the high cost of these investments. Moura (2004) agrees that there seems to be a higher cost added to products, which makes it less competitive in countries with strict environmental laws than in countries where legislation is less restrictive. The only reason why environmental management is still not practiced intensively is the high cost of investments in this area, and many companies do not have resources to streamline their processes. However, the cost of investment and technology in environmental management does not make ecologically-correct products economically impracticable. Environmental management factors are already included in the final cost. Moura (2004), Kinlaw (1997) and Voltolini (apud Vilela Júnior and Demajorovic, 2006) agree that the lack of a "green seal of approval" may represent a competitive factor or a reason for exclusion of products from demanding markets in the first world.

A good environmental management system in companies leads to cost reductions in production processes (Layrargues, 2000; Kinlaw, 1997; Maimon, 1996).

Corporate governance is the system that guides and monitors societies based on the relationship of shareholders or stockholders with the board of directors, the executive officers, the independent audit companies and the audit committee. Best practices of corporate governance aim at increasing the perceived value of the company in society, which facilitates raising funds and contributes to the company's perpetuation (IBGC, 2010).

\section{Material and Methods}

The audits conducted in the different editions of the Environmentally-Friendly Company certification, by Fundação Desenvolvimento Ambiental (FUNDAMENTAL), the environmental chapter of the Commercial and Industrial Association of Novo Hamburgo, Campo Bom and Estância Velha (ACI NH-CB-EV), were reviewed to compile data that, when interpreted, were used to evaluated the stage of corporate governance of the companies that voluntarily registered for certification, the entrepreneurial elite of the Sinos river valley in the state of Rio Grande do Sul, Brazil.

Currently, all employees, clients, suppliers, lenders, government and shareholders are stakeholders in the operation of organisations and should have their legitimate interests respected both by compliance with legislation and by voluntary adoption of practices and protocols by the organisations that protect their interests. 


\section{Results and Discussion}

The analysis of the 2009 final report of the voluntary certification of environmentally-friendly companies revealed that all certified companies met the environmental license criteria (Figure 1).

The figure above indicates that all companies that voluntarily participated in the 2009 edition of certification strictly met the criteria for environmental licensing in the competent government agencies according to auditing data.

Figure 2 shows data about the existence of effluent treatment plants.

All companies audited were classified into the two first categories. All the companies that should have effluent treatment plants (ETP) actually had them and submitted data about conformity to plant efficacy and control parameters required by the environmental agency. The other companies in the graph did not need ETP due to their activity, as expressed in their corporate purpose. In no case did audit identify the need of ETP in a company that did not have it.

Figure 3 below shows a compilation of data about solid residue management.

Most companies have already implemented a solid residue management system. It includes separation at origin, internal transportation, internal storage, enrichment, external destination for reuse, recycling or disposal in landfill. Part of this system was satisfactory, and part was registered as existing in the company. Only small companies with very limited corporate purposes did not have solid residue management systems. The nature and size of the operation in such cases did not demand it, and its absence did not lead to non-conformity with certification rules.

Figure 4 shows data about air monitoring. The definition of air pollution control is technically very clear about what types of businesses should keep such control. Initially, the activities with gas emissions into the atmosphere should always have an established monitoring system. However, the high costs of this activity and its relative operational complexity make it unaffordable for many businesses. Only very large companies, or companies associated with the petrochemical industry, have been relevant actors in air control or monitoring procedures at the current stage of industrial activities.

Figure 5 shows data about internal norms. Most companies do not have norms and recorded sets of rules, either in analogical or digital media. The few that do have them only confirm the rule.

In the classical items described in Figures 1 to 4, companies demonstrated that they only followed current and enacted legislation. Items 5 to 8, more adequate tools to interpret the several levels of corporate governance in companies, showed that corporate governance levels still tend to be low in higher ranks. Therefore, corporate governance principles are not disseminated or vertically interconnected in the companies, characteristics that, when present, may favour the decentralisation of power and the increase of generalised employee and collaborator

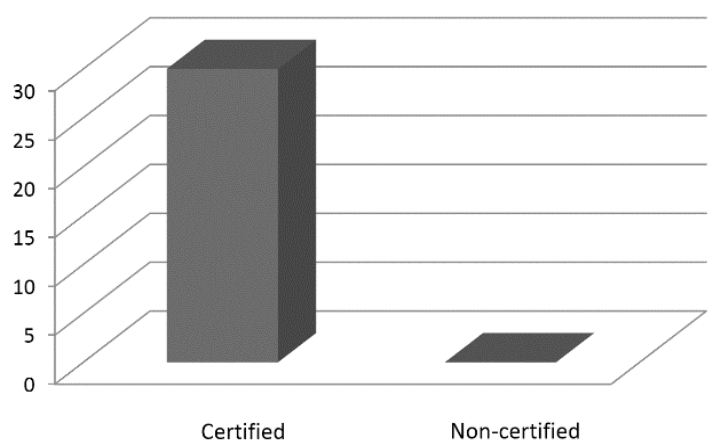

Figure 1. ACI NH-CB-EV voluntary certification as Environmentally-Friendly Company.

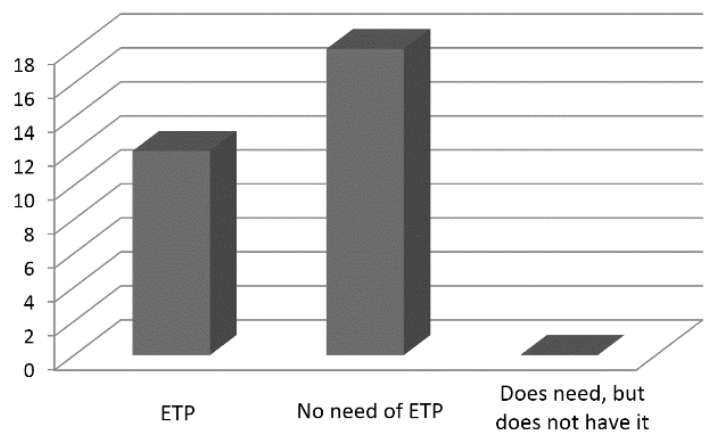

Figure 2. Effluent treatment plants in the companies audited.

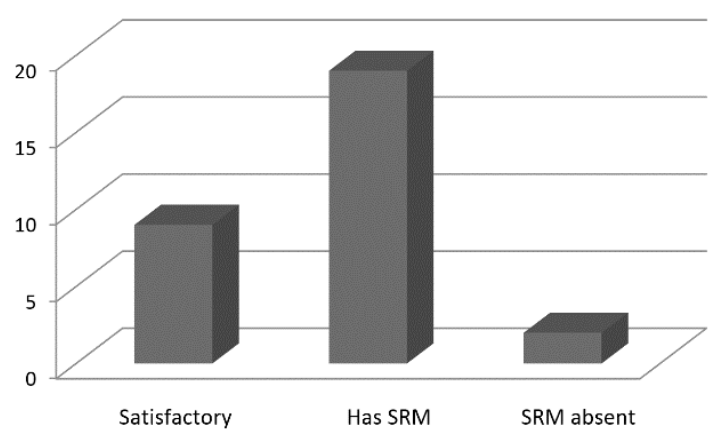

Figure 3. Solid residues management (SRM) in the companies that were audited.

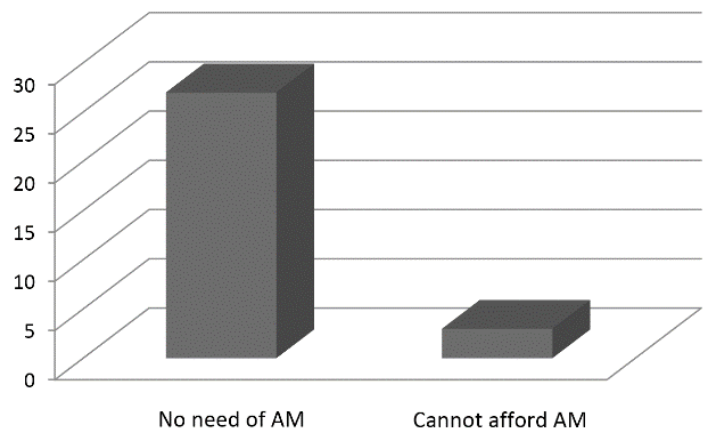

Figure 4. Air monitoring (AM) in the companies that underwent auditing. 


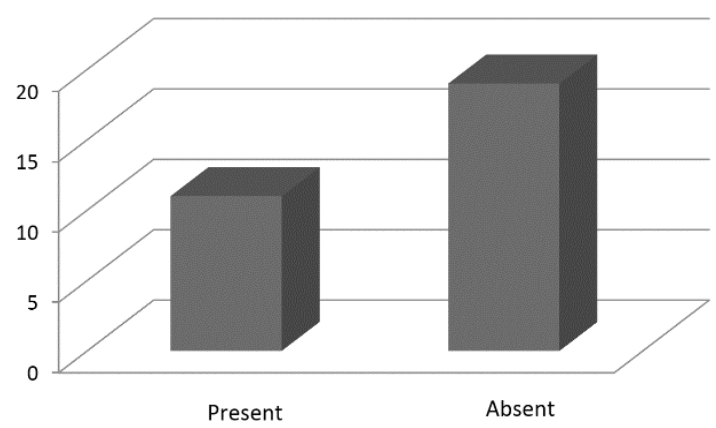

Figure 5. Presence or absence of internal norms in audited companies.

participation in implementing the initiatives that may add value to organisations and companies as a whole.

Figure 5 below shows data about the existence of internal norms to support systemic environmental management actions. Environmental management must be systematic, and actions cannot be unanticipated, fortuitous, unexpected, sudden, extraordinary, eccentric, outlandish (out of general use), random, aleatoric, self-willed, whimsical, voluble, inconstant, careless, incurious or negligent.

Figure 6 shows internal performance indices adopted by audited companies and organisations. These indices must be designed and improved along time so that the organisation or company moves towards a formal certification that requires the implementation and operation of Environmental Performance Indices (EPI).

Figure 7 shows whether there is an institutional representation in the corporate chart of the organisation or company.

The lack of representation in the corporate chart indicates a low level of corporate governance, together with all the consequences of such absence in the everyday operations of the organisation and at the different organisational ranks. This is compounded with the substantial number of audited organisations and businesses that are not familiar with this topic.

Figure 8 shows data on environmental education, which confirm the interpretation above. There is a predominance of sporadic actions or no actions, and very few companies have a systematic commitment to it.

Regardless of which concept of corporate governance is adopted, from the one used by the Brazilian Institute of Corporate Governance to more flexible interpretations, the meaning of restoring public trust in companies, organisations and businesses does not change. Therefore, corporate governance as a set of processes, customs, policies, laws, regulations and institutions that regulate the way the company is directed, managed and controlled and that is vertically interconnected and not restricted to the high administration seems to be an interpretation based on more solid grounds. The term also derives from the study of relations between all the stakeholders, thus called since the development of ISO norms. Stakeholders are all those interested in the company, which is currently legitimately

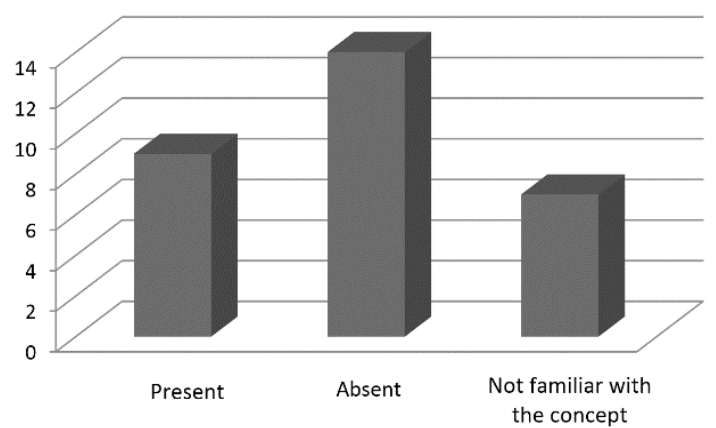

Figure 6. Internal performance indices (IPI).

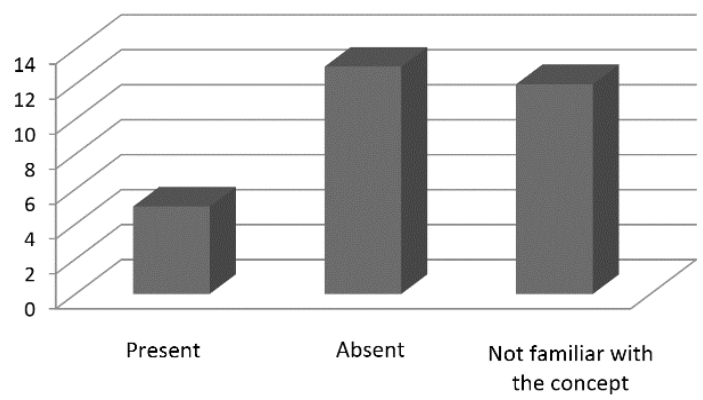

Figure 7. Institutional representation on the department responsible for environmental issues.

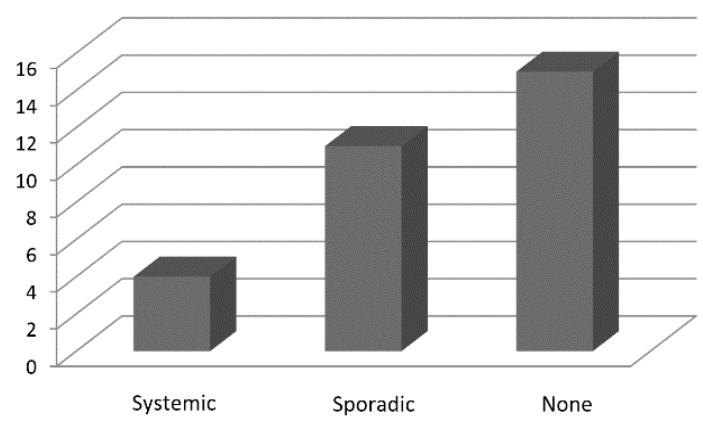

Figure 8. Frequency of environmental education actions.

understood as all clients, collaborators, neighbors, suppliers, government, NGOs and all other social actors that are, in any way, affected by the actions of the company, business or organisation.

\section{Conclusions}

In this study, basic concepts of environmental management, sustainable development and corporate governance were used to analyse data collected in auditing for voluntary environmental certification using items audited by the Environmentally-Friendly Company program sponsored by the Fundação Desenvolvimento Ambiental (FUNDAMENTAL) of the Commercial and 
Industrial Association of Novo Hamburgo, Campo Bom and Estância Velha. Our purpose was to diagnose the stage of adoption of basic corporate governance concepts in companies, businesses and organisations in the city of Novo Hamburgo, centrally located in the Sinos River basin, in the state of Rio Grande do Sul, Brazil.

The audited companies followed and conformed to all the items of applicable or relevant legislation. In this sense, they are in fact outstanding cases that deserve to be published and disseminated in the community as examples of actions resulting from collective socio-environmental responsibility.

When items not directly associated with applicable legislation were analysed, results did not reveal advances that may change bureaucratic environmental management that satisfactorily meets current normative requisites into systemic and proactive environmental management that may add value to enterprises.

The analysis of data collected from environmental management audits for voluntary environmental certification sponsored by the Commercial and Industrial Association of Novo Hamburgo, Campo Bom and Estância Velha did not reveal any actions that depend primarily on the internal redistribution of power and vertical interconnections, or that materialise corporate governance concepts that may add value to entrepreneurial operations and support company perpetuation.

\section{Acknowledgements}

We thank the Health Sciences Institute (ICS), the Exact and Technological Sciences Institute (ICET), the Graduate Programme in Environmental Quality and the Commercial and Industrial Association of Novo Hamburgo, Campo Bom and Estância Velha for the support provided for this study. FRS is a CNPq research fellow.

\section{References}

ANDRADE, ROB., TACHIZAWA, T. and CARVALHO, AB., 2002. Gestão ambiental - enforque estratégico aplicado ao desenvolvimento sustentável. 2nd. ed. São Paulo: Pearson Education do Brasil.

BOS, A., 2006. Barreiras técnicas ao comércio internacional de couros e calçados. São Paulo: Instituto de Pesquisas Tecnológicas do Estado de São Paulo. 174 p. Dissertação de Mestrado.
HENRIQUE, NMM., 2005. Comércio Internacional e seu impacto na cadeia do couro do Brasil. São Paulo: Oxiteno. Available from: $<$ http://www.aaqtic.org.ar/congresos/brasil2005/pdf/COMERCIO. pdf $>$. Access in: 03 Mar. 2010.

Instituto Brasileiro de Governança Corporativa - IBGC, 2010. Perguntas frequentes - o que é governança corporativa? IBGC. Available from: <http://www.ibgc.org.br/PerguntasFrequentes. aspx $>$. Access in: 23 Apr. 2010

KINLAW, DC., 1997. Empresa competitiva e ecológica: desempenho sustentado na era ambiental. São Paulo: Makron Books.

LAYRARGUES, PP., 2000. Sistemas de Gerenciamento Ambiental, tecnologia limpa e consumidor verde: a delicada relação empresameio ambiente no ecocapitalismo. Revista de Administração de empresas, vol. 40, no. 2, p. 80-88. http://dx.doi.org/10.1590/ S0034-75902000000200009.

MAIMON, D., 1996. Passaporte verde: gestão ambiental e competitividade. Rio de Janeiro: Qualitymark.

MOURA, LAA., 2003. Economia ambiental: gestão de custos e investimentos. 2nd ed. São Paulo: Editora Juarez de Oliveira.

MOURA, LAA., 2004. Qualidade e gestão ambiental. 4th ed. São Paulo: Editora Juarez de Oliveira.

NAIME, R., 2004. Diagnóstico ambiental e sistemas de gestão ambiental: incluindo a atualização da série ISO 9000 e as novas NBR 14000/2004 e NBR ISO 19011/2002. Novo Hamburgo: Feevale.

NAIME, R. and GARCIA, ACA., 2004. Percepção ambiental e diretrizes para compreender a questão do meio ambiente. Novo Hamburgo: Feevale. 135 p.

PÜNTENER, AG., 2007. REACH é um grande desafio para os importadores de produtos químicos e de couro para a União Européia. Revista do Couro, vol. 193, p. 33-36.

ROBBINS, SP., 2003. Administração: mudanças e perspectivas. São Paulo: Saraiva.

RUIZ, MS., BOS, A., NAGAMINE, R, FALEIROS, LC. and SOUZA, JDF., 2006. Exigências ambientais como barreiras ao comércio internacional de couros e artefatos: uma abordagem preliminar. In Workshop gestão integrada: risco e sustentabilidade, 2006. São Paulo. São Paulo, SENAC.

VILELA JUNIOR, A. and DEMAJOROVIC, J., editors, 2006. Modelos e ferramentas de gestão ambiental: desafios e perspectivas para as organizações. São Paulo: SENAC.

ZENONE, LC., 2006. Marketing social. São Paulo: Thomsom Learning. 